\title{
A grape seed extract maternal dietary supplementation improves egg quality and reduces ovarian steroidogenesis without affecting fertility parameters in reproductive hens: a link with plasma and ovarian cell adipokines expression?
}

\author{
Alix Barbe \\ INRA Centre Val de Loire \\ Namya Mellouk \\ INRA Centre Val de Loire \\ Christelle Ramé \\ INRA Centre Val de Loire \\ Jérémy Grandhaye \\ INRA Centre Val de Loire \\ Karine Anger \\ INRA Centre Val de Loire \\ Marine Chahnamian \\ INRA Centre Val de Loire \\ Patrice Ganier \\ INRA Centre Val de Loire \\ Aurélien Brionne \\ INRA Centre Val de Loire \\ Antonella Riva \\ Indena SpA \\ Pascal Froment \\ INRA Centre Val de Loire \\ joelle dupont ( $\nabla$ joelle.dupont@inra.fr ) \\ INRA Centre Val de Loire
}

\section{Research}

Keywords: Grape seed extract, reproduction, eggs, steroidogenesis, oxidative stress, broiler breeder hens

Posted Date: March 5th, 2020

DOI: https://doi.org/10.21203/rs.3.rs-16232/v1 
License: (1) This work is licensed under a Creative Commons Attribution 4.0 International License. Read Full License 


\section{Abstract}

Background: In mammals, oxidative stress (OS) induces negative effects on reproductive functions. In broiler hens, the genetic selection has increased susceptibility to OS. Grape seed extracts (GSE) are known as potent antioxidants. Here, we investigated the effects of time and level of GSE dietary supplementation on egg production and quality, fertility parameters, Reactive Oxygen Species (ROS) and steroid content in yolk egg associated to plasma adipokines in broiler hens.

Methods: We designed an in vivo study using four groups of hens: A (control), B and C (supplemented with GSE at $0.5 \%$ and $1 \%$ of the total diet composition, respectively, starting at week 4 ) and D (supplemented with GSE at $1 \%$ of the total diet composition since hatching). We assessed the egg production from 23 th to 40 th weeks and quality at 33 th week. After artificial inseminations, the fertility parameters were calculated. In egg yolk, Reactive Oxygen Species (ROS) level and steroid production were evaluated by Ros-Glo H202 and ELISA assay, respectively. Expression of steroidogenic enzymes and adipokines and their receptors was determined by RT-qPCR in ovarian cells and plasma adipokines (RARRES2, ADIPOQ and NAMPT) were evaluated by specific ELISA assays.

Results: The fertility parameters and egg production were unaffected by GSE supplementation. However, the rate of double-yolk eggs decreased for all GSE supplemented. Eggs from the C group were bigger and larger. The shell elasticity was higher for B and C groups. In the yolk egg, GSE supplementation reduced ROS content and steroidogenesis consistent with a decrease in P450 aromatase and StAR mRNA expression and basal in vitro progesterone secretion in granulosa cells. Interestingly, RARRES2 plasma levels were positively correlated while ADIPOQ and NAMPT plasma levels were negatively correlated, with steroids and ROS in yolk. Conclusions: Maternal dietary GSE supplementation did not affect egg production and fertility parameters whereas it reduced ROS content and steroidogenesis in yolk egg. Furthermore, it ameliorated egg quality by decreasing the number of double-yolk eggs and by improving the size of normal eggs and the elasticity of the shell. Taken together, our data suggest the possibility of using dietary maternal GSE to improve egg quality.

\section{Background}

Some evidence shows that various environmental and physiological insults may induce accumulation of Reactive Oxygen Species (ROS) leading to Oxidative Stress (OS). OS is defined as imbalance between the level of intracellular ROS production including superoxide anion (O2-), hydrogen peroxide (H2O2), and hydroxyl radicals $(-\mathrm{OH})$ and their scavenger by antioxidants $(1-3)$. ROS levels influence many physiological functions including reproduction. In the ovary, physiological ROS levels are generated due to increased metabolism during folliculogenesis, oocyte maturation $(4,5)$ and ovulation $(6,7)$. However, a strong rise of ROS levels, associated with a decrease of enzymatic antioxidants activity generates OS leading to damage of oocytes and granulosa cells within follicles (8-10). In rodents, ROS accumulation and OS induce granulosa cell apoptosis, oocyte dysfunction and antral follicles atresia (11-13). Growing evidence has shown that OS is associated with ovarian cells dysfunctions and lifestyle-related factors including nutrition style and body weight in human and rodents $(14,15)$. As in mammals, the reproductive performance of broiler breeder hens is strongly influenced by foods and type of nutrition. These animals fed ad libitum have been submitted to high selection pressure for growth and feed efficiency resulting in metabolic disorders and reproductive dysfunction (16-18). 
Nowadays, a restricting feed intake to approximately $60 \%$ of ad libitum is usual practice to prevents obesity, reduce mortality and to improve egg production in broiler hens (19). However, these breeding conditions are sources of stress and generate ROS and OS (20).

In mammals, several in vitro and in vivo studies have been carried out to use a supplementation of natural antioxidants of plant origin as a means of counteracting the oxidative stress conditions by restoring the cellular antioxidant defense mechanism. Grape seeds are proanthocyanidins, mainly composed of monomeric catechin and epicatechin, gallic acid, and polymeric and oligomeric proanthocyanidins (21) which have been demonstrated to be more powerful free radical scavengers than vitamins $C, E$, and $\beta$-carotene (22). The effects of grape seed extracts (GSE) have been largely investigated in cancer and metabolic cells (23) (24) but very few studies have been carried in ovarian cells. In mammals, GSE exerts in vivo beneficial effects on oxidative stress and on many metabolic disorders including insulin resistance (25) that could be associated to modulations of plasma adipokines such as adiponectin (26). Recently, we showed that GSE treatments reduced OS and improved in vitro steroidogenesis without affecting cell proliferation and viability in human granulosa cells (27). In hens, grape seed proanthocyanidin extract could prevent the ovarian aging process by reducing oxidative stress (28) and could provide some protection against the reproductive toxicity induced by the Cadmium endocrine disruptor (29). However, no studies investigated the in vivo effects of the GSE on the egg performance (quantity and quality) and on the fertility parameters. The ovary of the reproductively active hen represents an interesting model for studying follicular development. It consists of small prehierarchical and maturing preovulatory follicles showing a hierarchy according to their size (F5/6 to F1; (30). Moreover, as in women, ovarian functions in chicken are also regulated by gonadotropins, including FSH (follicle-stimulating hormone), LH (luteinizing hormone), and ovarian steroids. Thus, our present study aimed to determine the in vivo effects of time and level of maternal GSE dietary supplementation on egg production and quality, ROS levels and steroid composition in yolk and fertility parameters. Furthermore, we investigated a potential association between plasma adipokines and yolk ROS levels.

\section{Methods}

\section{Ethical issues}

An ethics committee “Comité d’Ethique en Expérimentation Animale Val de Loire » (CEEA VdL N¹9) protocol registered approved all experimental studies, which were in accordance with the French National Guidelines for the care and use of animals for research purposes (certificate of authorisation to experiment on living animals APAFIS number 10237-201706151202940v3).

\section{Animals}

Three hundred and twenty-four broiler breeder females chicks from Hendrix Genetics (Saint Laurent de la Plaine, France) were studied from day 1 to 40 weeks of age. Animals were divided in homogeneous groups of 10 to11 birds in 32 pens, each pen with an area of $3 \mathrm{~m}^{2}$. The animals were reared at "Pôle Expérimental Avicole de Tours" (INRA, Nouzilly, France) according to the conventional conditions of breeding: 24 h of light on arrival, day length being reduced to approximately $8 \mathrm{~h}$ at two days of age, then kept constant until the age of photostimulation (21st week). From 21 weeks of age, there was a gradual increase in exposure to light up to 
$15 \mathrm{~h}$ per day at 25 weeks. Animals were maintained under this light regime until the end of the experiment and then they were killed by electrical tunning and bled out as recommended by the ethical committee.

\section{Diets composition}

From one to the fourth week of age, female breeder chicks received an ad libitum diet (free access to food), called a starting diet. We used two types of diets: control and supplemented with $1 \%$ of GSE. At week 4 , all animals received a restricted diet according to Hendrix Genetics recommendation. Animals from the control group were segregated in 3 groups: control, supplemented with $0.5 \%$ and supplemented with $1 \%$ of GSE. The resulting four groups were: group $A$ (control, $n=92$ ), group B (supplemented with $0.5 \%$ of GSE since week 4 , $n$ $=80$ ), group C (supplemented with $1 \%$ of GSE since week $4, n=80$ ) and group D (supplemented with $1 \%$ of GSE since the hatch, $n=72$ ). From 4 week to 40 week, animals received three different diets: growing (from 4 to 18 week), before laying (from 18 week to 21 week) and laying (from 21 week to 40 week). Remaining feed was weighed. The composition of GSE used for this study was analysed by HPLC (High Performance Liquid Chromatography). The most important component was the procyanidins (>90\%). The supplement was manually mixed with the diet at the proper concentration of the total diet. The composition of the diets are shown in the additional file 1 (Table S1) and a schema of the experimental design is showed in additional file 2 (Figure S1)

\section{Measurement of egg production and quality}

From the 24th week, the eggs from each pen were collected twice a day, counted and weighted using a balance (Ohauss, Pionner) The numbers of normal and double (eggs with tw egg yolks) eggs were collected and counted. The weight of the albumen, the egg yolk and the dehydrated shell were determined. At the beginning of the laying period (26th week), the width and the length of the eggs laid for each group of animals were measured using a digital calliper (Mitutoyo, CD-20DCX). Using an Instron instrument (Instron, UK527), we analysed the static stiffness $(\mathrm{Sd}, \mathrm{N} / \mathrm{mm})$, the tensile strength $(\mathrm{F})$, the elastic modulus (Eshell, $\mathrm{N} / \mathrm{mm}^{2}$ ), the toughness $\left(\mathrm{Kc}, \mathrm{N} / \mathrm{mm}^{3}\right)$ of the eggs. The weight and the thickness of the shell were also measured. These parameters were assessed for 30 eggs of each group of animals.

\section{Determination of weight and number of follicles}

At 40 weeks old, 10 hens per group were selected and the preovulatory follicles (from 1 to 6 ) were collected, hierarchically defined and weighed. Granulosa cells and theca cells were collected from the F1.

\section{Fertility parameters}

For artificial insemination, we used the semen of 48 cocks (Cobb500), collected and pooled to form a single sample. The hens were inseminated with $2 \times 10^{8}$ spermatozoa, at 28 th and 33 rd week. Eggs were collected and counted daily for 3 weeks following the artificial insemination and incubated every seven days. We assessed the number of unfertilised eggs, early (EEM) and late (LEM) embryonic mortality by breaking eggs and candling on the 7th (EEM) and 14th (LEM) day of incubation. The different percentages (EEM, LEM, hatchability, hatchability of fertile eggs and fertility) were calculated using the following formulae:

$\% E E M=$ number of EEM / (number of incubated eggs - unfertilised eggs) * 100

$\%$ LEM = number of LEM / (number of incubated eggs - unfertilised eggs + number of EEM) * 100 
$\%$ Hatchability set $=$ (number of hatched chicks $/$ number of incubated eggs) $* 100$

$\%$ Hatchability of fertile eggs $=$ (number of hatched chicks / number of fertile eggs after 14 days of incubation $)$ * 100

\section{Measurement of progesterone, androstenedione, testosterone and oestradiol deposition in egg yolk}

We assessed steroids concentration from 30 egg yolks per group. Steroids were extracted with diethyl ether after intense agitation and centrifugation. The steroid-containing diethyl ether phase was decanted after freezing the tubes in nitrogen for $10 \mathrm{~s}$. The organic solvents were then evaporated and the extracts taken up in phosphate buffer. Steroid hormones (progesterone, oestradiol, testosterone and androstenedione) were then measured in the extracts using ELISA assays. For progesterone, the ELISA assay was performed as described by (31). The sensitivity of the assay was $0.4 \mathrm{ng} / \mathrm{mL}$. Oestradiol and testosterone concentrations were determined using commercial ELISA assays from Cayman Chemicals and the sensitivity of these assays was $0.01 \mathrm{ng} / \mathrm{mL}$. Androstenedione levels were analysed using an ELISA assay from Abcam and the sensitivity of the assay was $0.01 \mathrm{ng} / \mathrm{mL}$. The intra-assay and inter-assay coefficients of variation (CV) for each assay averaged $<10 \%$.

\section{Measurements of the expression of steroidogenic genes in granulosa cells}

Total RNA from granulosa cells of preovulatory follicle 1 of ten animals per group was extracted by homogeneisation in the TRIzol tissue reagent using an ULTRATURAX instrument, according to the manufacturer's recommendations (Invitrogen, by Life Technologies, Villebon sur Yvette, France). The cDNA was generated by reverse transcription of total RNA $(2 \mu \mathrm{g})$ in a mixture comprising $0.5 \mathrm{mM}$ of each deoxyribonucleotide triphosphate (dATP, dTTP, dGTP, dCTP), 2 M of RT Buffer, $15 \mu \mathrm{g} / \mu \mathrm{L}$ of oligodT, $0.125 \mathrm{U}$ of ribonuclease inhibitor, and $0.05 \mathrm{U}$ of Moloney murine leukemia virus reverse transcriptase (MMLV) for one hour at $37^{\circ} \mathrm{C}$. Real-time PCR was performed using the MyiQ Cycle Device (Bio-Rad, Marnes-la-Coquette, France), in a mixture with SYBR Green Supermix 1X Reagent (Bio-Rad, Marnes-la-Coquette, France), 250 nM specific primers (Invitrogen by Life Technologies, Villebon-sur-Yvette, France) and $3 \mu \mathrm{L}$ of cDNA diluted 1:5 in water) for a total volume of $11 \mu \mathrm{L}$. The samples were set up in duplicate on the same plate according to the following procedure: after an incubation of $2 \mathrm{~min}$ at $50{ }^{\circ} \mathrm{C}$ and a denaturation step of $10 \mathrm{~min}$ at $95^{\circ} \mathrm{C}$, samples were subjected to 40 PCR cycles $\left(30 \mathrm{~s}\right.$ at $95^{\circ} \mathrm{C}, 30 \mathrm{~s}$ at $60^{\circ} \mathrm{C}, 30 \mathrm{~s}$ at $\left.72{ }^{\circ} \mathrm{C}\right)$. The primers used are shown in the additional file 3 (Table S2). For each gene, the relative abundance of transcription was determined by calculating $\mathrm{e}^{-\mathrm{ct}}$. Then, the relative expression of the gene of interest was related to the relative expression of the geometric mean of the three reference genes (GAPDH, ACTB and EIF3).

\section{In vitro culture of hen granulosa cells}

Granulosa cells from preovulatory follicles 1 (F1) of hens fed with GSE dietary supplementation or with a control diet were collected from 7 animals for each group. Then, cells were dispersed in $0.3 \%$ collagenase type A (Roche Diagnostic, Meylan, France) in F12 medium containing 5\% foetal bovine serum (FBS), at $37^{\circ} \mathrm{C}$. Cells were pelleted by centrifugation, washed twice with fresh medium and counted in a haemocytometer. The viability of granulosa cells was estimated by Trypan Blue exclusion. Cells were cultured in a medium 
composed of DMEM supplemented with $100 \mathrm{U} / \mathrm{mL}$ penicillin, $100 \mathrm{mg} / \mathrm{L}$ streptomycin, $3 \mathrm{mmol} / \mathrm{L}$ L-glutamine and $5 \%$ FBS. The cells were initially cultured for $24 \mathrm{~h}$ with no treatment. After overnight serum deprivation, cells collected from hens Rhode Island were stimulated with GSE $(0.01,0.1,1,50$ and $100 \mu \mathrm{g} / \mathrm{mL})$ or left untreated for $48 \mathrm{~h}$. Cells collected from hens fed with GSE supplementation were stimulated with IGF1 $\left(10^{-8} \mathrm{M}\right)$, LH (10 $\left.{ }^{8} \mathrm{M}\right)$, IGF1 $+\mathrm{LH}\left(10^{-8} \mathrm{M}\right)$ or left untreated. All cultures were maintained under a water-saturated atmosphere of $95 \%$ air/ $5 \% \mathrm{CO} 2$ at $37^{\circ} \mathrm{C}$.

\section{In vitro measurement of progesterone secretion by granulosa cells}

The concentration of progesterone secreted into the medium by granulosa cells under various conditions was determined according to an ELISA protocol described by (31). The sensitivity of the kit was $0.4 \mathrm{ng} / \mathrm{mL}$. The intra- and inter-assay coefficients of variation were $<10 \%$ and $<4.3 \%$ respectively. This experiment was carried out using four replicates of three hens for each group.

\section{Adipokine assays}

Plasma concentration of three adipokines were determined using ELISA assays. Chicken-specific kits, MBS269004 (sensitivity $5 \mathrm{pg} / \mathrm{mL}$ ), MBS016609 (sensitivity $0.1 \mu \mathrm{g} / \mathrm{mL}$ ) and MBS738819 (sensitivity $0.1 \mathrm{ng} / \mathrm{mL}$ ), were used for NAMPT, ADIPOQ and RARRES2 respectively (My BioSource). The experiment was performed following the manufacturer's protocol with an intra-assay coefficient of variation $\leq 8 \%,<15 \%$ and $<$ 5.6 respectively. The absorbance was measured at $450 \mathrm{~nm}$ and then compared with reference values.

\section{Measurement of ROS (hydrogen peroxide ( $\mathrm{HXOQ)}$ in yolk}

The content of ROS, hydrogen peroxide ( $\mathrm{H} 囚 \mathrm{O} \otimes)$ from 10 egg yolks per group were measured by Ros-Glo H2O2 assay (Promega Corporation, Charbonnières-les-Bains, France). In each analysis, one gram of each egg yolk for each group was precisely analysed following the manufacturer's protocol.

\section{Statistical analysis}

Data are represented as mean \pm s.e.m., with a level of significance less than $0.05\left({ }^{*} \mathrm{P}<0.05\right)$. An analysis of variance using repeated measurements (Proc.Mix procedure) was used to compare the average numbers of normal eggs among the different hen groups over time. An analysis of variance (Proc.GLM procedure) was used to compare the number of double-yolk eggs, the weight of follicles, the content of ROS, the average concentrations of secreted steroids and androgen and levels of expression of adipokines and their receptors among the different groups. Two factors were analysed: the time of GSE supplementation (from birth (one day of age, D group) compared from 28 days (week $4, B$ and $C$ groups)) and a diet effect. If the time of GSE supplementation was significant, we analysed separately the diets $A$ and $D$, and $A, B$ and $C$ and if not we compared the whole $A, B, C$ and $D$ groups. A chi-square test was used for analysis of percentage fertility between the different parameters. A Pearson test was used to analyse correlations between ROS content and steroid in yolk egg and plasma adipokine concentration. The correlation was noted ' $r$ ' and the P value was considered significant if $P<0.05$. SAS software (version 9.3, Cary, USA) was used for all analyses. Different letters indicate significant differences $(P<0.05)$. 


\section{Effect of GSE maternal dietary supplementation on the egg production and quality}

The number of normal laying eggs per hen per day, the age at the first egg or at the laying peak were unaffected by the GSE dietary supplementation (Table 1 and Fig. 1.A). As shown in Table 1, the number of normal laying eggs per hen and per day in whole period (from week 23 to week 40) was similar between the different groups of animals whereas that of double laying eggs was significantly reduced by the GSE maternal dietary supplementation (Fig. 1.B). Indeed, GSE dietary supplementation reduced the number of double egg in $B, C$ and $D$ groups as compared to the control $(B: 0.33 \pm 0.07 ; C: 0.22 \pm 0.05 ; D: 0.21 \pm 0.05$ vs $A: 0.56 \pm 0.11 ; P$ $<0.05)$. Furthermore, for this latter parameter, we observed a significant time effect of the GSE $1 \%$ supplementation $(P=0.003$, start at hatch versus start at week 4$)$. At week 26 , we assessed different parameters concerning the quality of eggs (Table 1 ). We noted that the weight of eggs was significantly increased in $C$ group of animals $(P<0.02)$ and this was associated with a higher length $(P<0.0001)$ and width $(P<0.0001)$ of eggs without any variation in the yolk and albumen weight (Table 1). On the other hand, the Eshell corresponding to the elasticity of the shell was significantly higher in the $B$ and $C$ groups $(P=0.0003)$ whereas it was unaffected in group D compared with the control animals (Table 1). The percentage of shell, the toughness and thickness of the shell, the tensile strength and the static stiffness were similar in all GSE supplemented group and control group (Table 1). 
Table 1

Number and quality of laying eggs of broiler hens fed with a GSE diet supplemented.

\begin{tabular}{|c|c|c|c|c|c|c|c|c|}
\hline Parameters & A & B & C & D & TimeSuppl & $\begin{array}{l}\text { Diet } \\
\text { ABCD }\end{array}$ & $\begin{array}{l}\text { Diet } \\
A B C\end{array}$ & $\begin{array}{l}\text { Diet } \\
A D\end{array}$ \\
\hline $\begin{array}{l}\text { Number of } \\
\text { normal laying } \\
\text { egg / hen/day }\end{array}$ & $\begin{array}{l}0.59 \pm \\
0.21\end{array}$ & $\begin{array}{l}0.59 \pm \\
0.24\end{array}$ & $\begin{array}{l}0.58 \pm \\
0.23\end{array}$ & $\begin{array}{l}0.55 \pm \\
0.26\end{array}$ & 0.34 & 0.49 & - & - \\
\hline $\begin{array}{l}\text { Number of } \\
\text { double-yolk } \\
\text { eggs /hen/day }\end{array}$ & $\begin{array}{l}0.56 \pm \\
0.11^{a}\end{array}$ & $\begin{array}{l}0.33 \pm \\
0.07^{b}\end{array}$ & $\begin{array}{l}0.22 \pm \\
0.05^{b}\end{array}$ & $\begin{array}{l}0.21 \pm \\
0.05\end{array}$ & 0.003 & - & 0.01 & 0.02 \\
\hline $\begin{array}{l}\text { Age for the first } \\
\text { egg (week) }\end{array}$ & $\begin{array}{l}24.25 \pm \\
0.25\end{array}$ & $\begin{array}{l}24.57 \pm \\
0.3\end{array}$ & $\begin{array}{l}24.29 \pm \\
0.18\end{array}$ & $\begin{array}{l}24.2 \pm \\
0.37\end{array}$ & 0.76 & 0.77 & - & - \\
\hline $\begin{array}{l}\text { Age at the } \\
\text { laying peak } \\
\text { (week) }\end{array}$ & $\begin{array}{l}29.38 \pm \\
0.63\end{array}$ & $\begin{array}{l}31.71 \pm \\
0.8\end{array}$ & $\begin{array}{l}29.86 \pm \\
0.4\end{array}$ & $\begin{array}{l}30.8 \pm \\
0.8\end{array}$ & 0.21 & 0.08 & - & - \\
\hline Egg weight (g) & $\begin{array}{l}52.37 \pm \\
0.57^{a}\end{array}$ & $\begin{array}{l}53.88 \pm \\
0.6^{a}\end{array}$ & $\begin{array}{l}54.59 \pm \\
0.62^{b}\end{array}$ & $\begin{array}{l}53.61 \pm \\
0.79\end{array}$ & 0.03 & - & 0.02 & 0.2 \\
\hline Yolk weight (g) & $\begin{array}{l}14.02 \pm \\
0.15\end{array}$ & $\begin{array}{l}14.35 \pm \\
0.23\end{array}$ & $\begin{array}{l}14.39 \pm \\
0.21\end{array}$ & $\begin{array}{l}14.13 \pm \\
0.24\end{array}$ & 0.17 & 0.31 & - & - \\
\hline $\begin{array}{l}\text { Albumen weight } \\
\text { (g) }\end{array}$ & $\begin{array}{l}30.27 \pm \\
0.43\end{array}$ & $\begin{array}{l}31.12 \pm \\
0.84\end{array}$ & $\begin{array}{l}31 \pm \\
0.53\end{array}$ & $\begin{array}{l}30.51 \pm \\
0.63\end{array}$ & 0.42 & 0.63 & - & - \\
\hline Length (mm) & $\begin{array}{l}50.79 \pm \\
0.5^{a}\end{array}$ & $\begin{array}{l}54.68 \pm \\
0.32^{b}\end{array}$ & $\begin{array}{l}55.33^{ \pm} \\
0.26^{b}\end{array}$ & $\begin{array}{l}54.84 \pm \\
0.27\end{array}$ & $<0.0001$ & - & $\begin{array}{l}< \\
0.0001\end{array}$ & $\begin{array}{l}< \\
0.0001\end{array}$ \\
\hline Width (mm) & $\begin{array}{l}38.09 \pm \\
0.401^{a}\end{array}$ & $\begin{array}{l}42.04 \pm \\
0.2^{b}\end{array}$ & $\begin{array}{l}41.74 \pm \\
0.23^{b}\end{array}$ & $\begin{array}{l}41.72 \pm \\
0.3\end{array}$ & $<0.0001$ & - & $\begin{array}{l}< \\
0.0001\end{array}$ & $\begin{array}{l}< \\
0.0001\end{array}$ \\
\hline$\%$ of shell & $\begin{array}{l}9.36 \pm \\
0.13\end{array}$ & $\begin{array}{l}9.24 \pm \\
0.16\end{array}$ & $\begin{array}{l}9.34 \pm \\
0.11\end{array}$ & $\begin{array}{l}9.09 \pm \\
0.14\end{array}$ & 0.33 & 0.49 & - & - \\
\hline $\begin{array}{l}\text { Thickness } \\
(\mathrm{mm})\end{array}$ & $\begin{array}{l}0.319 \pm \\
0.01\end{array}$ & $\begin{array}{l}0.322 \pm \\
0.01\end{array}$ & $\begin{array}{l}0.322 \pm \\
0.004\end{array}$ & $\begin{array}{l}0.312 \pm \\
0.01\end{array}$ & 0.38 & 0.55 & - & - \\
\hline $\begin{array}{l}\text { Toughness } \\
\text { (N/mm3) }\end{array}$ & $\begin{array}{l}486.01 \\
\pm 7.7\end{array}$ & $\begin{array}{l}481.17 \\
\pm 8.45\end{array}$ & $\begin{array}{l}470.37 \\
\pm 10.78\end{array}$ & $\begin{array}{l}463.17 \\
\pm 11.14\end{array}$ & 0.21 & 0.3 & - & - \\
\hline Eshell (N/mm²) & $\begin{array}{l}16640 \\
\pm \\
357.55 \\
a\end{array}$ & $\begin{array}{l}18546 \\
\pm \\
391.05 \\
b\end{array}$ & $\begin{array}{l}18659 \\
\pm \\
450.15 \\
b\end{array}$ & $\begin{array}{l}17738 \\
\pm \\
507.53\end{array}$ & 0.0005 & - & 0.0003 & 0.07 \\
\hline
\end{tabular}

Group A: animals fed with control diet without GSE supplementation, B and C: animals supplemented with GSE at $0.5 \%$ and $1 \%$ of the total diet composition, respectively, starting at 4 week-old until 40 week-old and D: supplementation at $1 \%$ of the total diet composition starting at hatch until 40 week-old. The number of laying egg was determined in the whole period from 23 to 40th week including all animals and the quality of eggs was determined at 26th week on 30 eggs from each group of animals. Results are presented as Ismeans \pm SEM. P values of the effect of the stage when the supplementation is applied (TimeSuppl). Different individual letters indicate a significant effect of the diet. 


\begin{tabular}{|c|c|c|c|c|c|c|c|c|}
\hline Parameters & A & B & C & D & TimeSuppl & $\begin{array}{l}\text { Diet } \\
\text { ABCD }\end{array}$ & $\begin{array}{l}\text { Diet } \\
A B C\end{array}$ & $\begin{array}{l}\text { Diet } \\
A D\end{array}$ \\
\hline $\begin{array}{l}\text { Tensile strengh } \\
(\mathrm{N})\end{array}$ & $\begin{array}{l}32.93 \pm \\
0.84\end{array}$ & $\begin{array}{l}34.52 \pm \\
0.91\end{array}$ & $\begin{array}{l}33.53 \pm \\
0.78\end{array}$ & $\begin{array}{l}31.28 \pm \\
1.02\end{array}$ & 0.07 & 0.13 & - & - \\
\hline $\begin{array}{l}\text { Static stiffness } \\
(\mathrm{N} / \mathrm{mm})\end{array}$ & $\begin{array}{l}156.9 \pm \\
4.05\end{array}$ & $\begin{array}{l}164.5 \pm \\
3.91\end{array}$ & $\begin{array}{l}157.2 \pm \\
4.3\end{array}$ & $\begin{array}{l}152.2 \pm \\
5.98\end{array}$ & 0.41 & 0.3 & - & - \\
\hline \multicolumn{9}{|c|}{$\begin{array}{l}\text { Group A: animals fed with control diet without GSE supplementation, B and C: animals supplemented with } \\
\text { GSE at } 0.5 \% \text { and } 1 \% \text { of the total diet composition, respectively, starting at } 4 \text { week-old until } 40 \text { week-old an } \\
\text { D: supplementation at } 1 \% \text { of the total diet composition starting at hatch until } 40 \text { week-old. The number of } \\
\text { laying egg was determined in the whole period from } 23 \text { to } 40 \text { th week including all animals and the quality } \\
\text { of eggs was determined at } 26 \text { th week on } 30 \text { eggs from each group of animals. Results are presented as } \\
\text { Ismeans } \pm \text { SEM. P values of the effect of the stage when the supplementation is applied (TimeSuppl). } \\
\text { Different individual letters indicate a significant effect of the diet. }\end{array}$} \\
\hline
\end{tabular}

\section{Effect of GSE supplementation on weight of follicles and fertility parameters}

We weighed the preovulatory follicles from 1 to 6 (F1 to F6), for 10 animals per group of animals. The GSE dietary supplementation did not affect the weight of F1, F2 (Fig. 2.A and B) F5 and F6 (data not shown). Only the supplementation of $1 \%$ GSE from week 4 significantly reduced the weight of the preovulatory follicle $3(P=$ 0.03 , Fig. 2.C) and 4 ( $P=0.02$, Fig. 2.D) as compared to other group of animals. After the first artificial insemination (Al) at 28 weeks, we assessed the fertility parameters (Table 2). The GSE supplementation did not affect the percentage of unfertilized eggs, the EEM, LEM, the hatchability of incubated eggs and the fertility rate (Table 2). However, we observed a decreasing trend for the hatchability of fertile eggs parameter $(P=0.06)$ in response to GSE dietary supplementation. For all fertility parameters, we found similar data for the second Al (33 weeks). 
Table 2

Percentage of unfertilised eggs, early (EEM) and late (LEM) embryonic mortality and fertility after artificial insemination in broiler hens fed with GSE supplementation.

\begin{tabular}{|c|c|c|c|c|c|}
\hline Parameters & A & B & C & D & Diet \\
\hline$\%$ Unfertilised & $5.89 \pm 0.89$ & $4.23 \pm 0.65$ & $4.06 \pm 0.75$ & $6.28 \pm 0.99$ & 0.27 \\
\hline$\%$ EEM & $4.62 \pm 0.69$ & $4.49 \pm 0.55$ & $5.46 \pm 0.65$ & $3.89 \pm 0.54$ & 0.25 \\
\hline$\%$ LEM & $1.29 \pm 0.47$ & $1.2 \pm 0.28$ & $1.33 \pm 0.33$ & $1.12 \pm 0.37$ & 0.47 \\
\hline \% Fertility & $88.8 \pm 1.19$ & $90.53 \pm 0.76$ & $89.73 \pm 1.11$ & $89.17 \pm 1.15$ & 0.34 \\
\hline$\%$ Hatchability of incubated eggs & $79.88 \pm 1.04$ & $79.55 \pm 0.99$ & $79.87 \pm 1.15$ & $77.5 \pm 1.38$ & 0.57 \\
\hline$\%$ Hatchability of fertile eggs & $90.05 \pm 0.64$ & $87.93 \pm 1.01$ & $89.05 \pm 0.83$ & $86.86 \pm 0.88$ & 0.06 \\
\hline \multicolumn{6}{|c|}{$\begin{array}{l}\text { Results are presented as Ismeans } \pm \text { SEM; } P \text { values of the effects of diet were considered as significant if } P \\
<0.05 \text {. EEM, early embryonic mortality; LEM, late embryonic mortality. A: animals fed with control diet } \\
\text { without GSE supplementation, B and C: animals supplemented with GSE at } 0.5 \% \text { and } 1 \% \text { of the total diet } \\
\text { composition, respectively, starting at } 4 \text { week-old until } 40 \text { week-old and D: supplementation at } 1 \% \text { of the } \\
\text { total diet composition starting at hatch until } 40 \text { week-old. }\end{array}$} \\
\hline
\end{tabular}

Effect of GSE supplementation on steroids hormones concentration in egg yolks and mRNA expression of steroidogenic enzymes in granulosa cells

As shown in Fig. 3 and Table 3, the production of progesterone (Fig. 3.A), testosterone (Fig. 3.B) and androstenedione (Fig. 3.C) in the egg yolks was significantly lower $(P<0.0001)$ for all dietary GSE supplemented groups compared to the control group. In addition, we noticed that oestradiol concentration in the egg yolks was reduced only for $B(P=0.0003)$ and $D(P=0.001)$ groups compared to the control (Fig. 3.D). In addition, for each of these hormonal parameters, we observed a significant effect of the period of the GSE supplementation ((start at hatch (D group) versus start at week 4 (B and C group), $\mathrm{P}<0.0001$ for progesterone, testosterone and androstendione and $\mathrm{P}=0.01$ for oestradiol). We next examined whether this decrease in steroid concentration in egg yolks in response to a GSE dietary supplementation was a result of some key enzymes of steroidogenesis (3ß-HSD, P450scc, P450 aromatase) and/or of StAR, an important cholesterol carrier in the granulosa cells from F1 preovulatory follicle. As shown in Fig. 3.E and 3.F, we showed that the mRNA expression of P450 aromatase (Fig. 3.E) and StAR (Fig. 3.F) was significantly reduced in C and D groups compared to the control group $(P<0.0001)$ whereas the mRNA expression of the other enzymes $(3 \beta-$ HSD and P450scc) was unaffected. 
Table 3

Progesterone, testosterone, androstenedione and oestradiol concentrations in egg yolk at 33 weeks-old.

\begin{tabular}{|c|c|c|c|c|c|}
\hline Period & Group & $\begin{array}{l}\text { Progesterone } \\
(\mathrm{ng} / \mathrm{g})\end{array}$ & $\begin{array}{l}\text { Testosterone } \\
\text { (ng/g) }\end{array}$ & $\begin{array}{l}\text { Androstenedione } \\
\text { (ng/g) }\end{array}$ & $\begin{array}{l}\text { Oestradiol } \\
\text { (ng/g) }\end{array}$ \\
\hline \multirow[t]{4}{*}{$\begin{array}{l}33 \\
\text { weeks }\end{array}$} & $A$ & $3846 \pm 53.47^{a}$ & $3.3 \pm 0.06^{a}$ & $540.5 \pm 5.26^{a}$ & $4.66 \pm 0.07^{a}$ \\
\hline & B & $2839 \pm 63.82^{b}$ & $2.21 \pm 0.04^{b}$ & $235.2 \pm 4.45^{b}$ & $4.15 \pm 0.13^{b}$ \\
\hline & C & $2827 \pm 45.1^{b}$ & $1.69 \pm 0.06^{c}$ & $243.4 \pm 6.21^{b}$ & $4.58 \pm 0.06^{a}$ \\
\hline & $\mathrm{D}$ & $2679 \pm 42.47$ & $2.07 \pm 0.05$ & $271.2 \pm 7.54$ & $4.33 \pm 0.06$ \\
\hline$P$ & TimeSuppl & $<0.0001$ & $<0.0001$ & $<0.0001$ & 0.01 \\
\hline$P$ & Diet ABCD & - & - & - & - \\
\hline$P$ & Diet ABC & $<0.0001$ & $<0.0001$ & $<0.0001$ & 0.0003 \\
\hline$P$ & Diet AD & $<0.0001$ & $<0.0001$ & $<0.0001$ & 0.001 \\
\hline \multicolumn{6}{|c|}{$\begin{array}{l}\text { Results are presented as Ismeans } \pm \text { SEM. P values of the effect of the stage when the supplementation is } \\
\text { applied (TimeSuppl) and diet were considered as significant if } P<0.05 \text {. Different individual letters indicate } \\
\text { a significant effect of the diet. Thirty eggs yolk were collected from broiler hens fed with different } \\
\text { concentrations of GSE dietary supplementation or with a control diet. A: animals fed with control diet } \\
\text { without GSE supplementation, B and C: animals supplemented with GSE at } 0.5 \% \text { and } 1 \% \text { of the total diet } \\
\text { composition, respectively, starting at } 4 \text { week-old until } 40 \text { week-old, and D: supplementation at } 1 \% \text { of the } \\
\text { total diet composition starting at hatch until } 40 \text { week-old. }\end{array}$} \\
\hline
\end{tabular}

Effects of GSE dietary supplementation on in vitro steroidogenesis in hen primary granulosa cells

As was the case for egg yolks, the GSE dietary supplementation significantly decreased the production of progesterone by unstimulated primary granulosa cells from $F 1$ preovulatory follicles $(P<0.0001$, Fig. 4.A). However, after stimulation of cells with IGF1 $\left(10^{-8} \mathrm{M}\right)$ or LH $\left(10^{-8} \mathrm{M}\right)$ alone or in combination, the GSE dietary supplementation significantly increased the granulosa cells response suggesting a better sensitivity of cells to these hormones $(P<0.005$, Fig. 4.B).

\section{Effect of GSE dietary supplementation on Reactive Oxygen Species (ROS) levels in egg yolks}

Since some studies demonstrated that GSE were powerful free radical scavengers (22), we consequently evaluated by using Ros-Glo H202 assay the ROS (H202) amount in egg yolks. As shown in Fig. 5, the GSE significantly decreased the ROS levels $(P<0.0001)$ in eggs yolks whatever the beginning of the maternal dietary supplementation period (hatching (D group) or week 4 ( $B$ ad $C$ group). In addition, when the GSE supplementation was applied at week 4, the ROS levels were lower in C as compared to B group showing a dose dependent decrease (Fig. 5).

Effect of the GSE dietary supplementation on adipokines plasma levels and association with steroids hormones and ROS amount in egg yolks 
Since we previously showed that plasma adipokines could be associated to fertility parameters in hens (32), we assessed the plasma concentration of RARRES2 (Fig. 6.A), ADIPOQ (Fig. 6.B) and NAMPT (Fig. 6.C) at 33 weeks before the second Al. The plasma RARRES2 concentration significantly decreased whereas plasma ADIPOQ and NAMPT concentrations increased in all GSE dietary supplemented groups compared to the control $(\mathrm{P}<0.0001)$. Then, we assessed the correlation between these plasma adipokines and the steroids hormones in yolk eggs (Table 4). Progesterone, androstenedione and testosterone concentrations in yolk eggs were positively correlated with plasma RARRES2 $(r=0.69, r=0.71$ and $r=0.71$, respectively, $P<0.0001)$ whereas they were negatively correlated with plasma ADIPOQ $(r=-0.71, r=-0.65$ and $r=-0.75$, respectively, $P<$ $0.0001)$ and plasma NAMPT $(r=-0.65, r=-0.6$ and $r=-0.62$, respectively, $P<0.0001)$. Any correlation was significant for plasma oestradiol concentration. Moreover, we observed that ROS levels in yolk eggs were positively correlated with plasma RARRES2 $(r=0.81, P<0.0001)$ and negatively correlated with plasma ADIPOQ $(r=-0.74, P<0.0001)$ and plasma NAMPT $(r=-0.66, P<0.0001)$.

Table 4

Pearson correlation coefficient ( $r$ ) calculated between plasma adipokines (RARRES2, ADIPOQ, NAMPT) concentration and steroids hormones (progesterone, androstenedione, testosterone, oestradiol) and ROS concentration in egg yolk.

\begin{tabular}{|c|c|c|c|c|}
\hline Groups ABCD & & RARRES2 & ADIPOQ & NAMPT \\
\hline \multirow[t]{2}{*}{ Progesterone } & $r$ & 0.69 & -0.71 & -0.65 \\
\hline & P-value & $<0.0001$ & $<0.0001$ & $<0.0001$ \\
\hline \multirow[t]{2}{*}{ Androstenedione } & $r$ & 0.71 & -0.65 & -0.6 \\
\hline & P-value & $<0.0001$ & $<0.0001$ & $<0.0001$ \\
\hline \multirow[t]{2}{*}{ Testosterone } & $r$ & 0.71 & -0.75 & -0.62 \\
\hline & P-value & $<0.0001$ & $<0.0001$ & $<0.0001$ \\
\hline \multirow[t]{2}{*}{ Oestradiol } & $r$ & 0.13 & 0.05 & -0.07 \\
\hline & P-value & 0.4 & 0.75 & 0.63 \\
\hline \multirow[t]{2}{*}{ Reactive Oxygen Species (ROS) } & $r$ & 0.81 & -0.74 & -0.66 \\
\hline & P-value & $<0.0001$ & $<0.0001$ & $<0.0001$ \\
\hline \multicolumn{5}{|c|}{$\begin{array}{l}\text { Values }(r) \text { and significance ( } P \text {-value) of the correlations are indicated. Correlations were considered as } \\
\text { significant if } P<0.05 \text {. Groups: A (no supplementation), B (supplemented with } 0.5 \% \text { of the total diet } \\
\text { composition starting at } 4 \text { week-old until } 40 \text { week-old), } C \text { (supplemented with } 1 \% \text { of the total diet } \\
\text { composition starting at } 4 \text { week-old until } 40 \text { we eks-old) and D (supplemented with } 1 \% \text { of the total diet } \\
\text { composition starting at hatch until } 40 \text { week-old). }\end{array}$} \\
\hline
\end{tabular}

Effect of the GSE dietary supplementation on the expression of adipokines and their receptors in granulosa and theca cells

In granulosa and theca cells from F1 preovulatory follicles, we determined the effect of the GSE dietary supplementation on the mRNA expression (Table 5) of all adipokines (RARRES2, ADIPOQ, NAMPT) and their 
receptors (CMKLR1, CCRL2, GPR1, ADIPOR1, ADIPOR2). There was no effect of GSE supplementation in RARRES2 expression in granulosa cells, however we observed a decrease in the mRNA expression of its main receptor CMKLR1 $(P=0.05)$ in the $C$ group compared to the control. In addition we showed a decrease in GPR1 expression in all GSE dietary supplemented group as compared the control (Table 5). In granulosa cells, ADIPOQ was undetectable. However, we detected a significant decrease of the expression of ADIPOR1 for the D group compared to the control $(P<0.05)$. Concerning the expression of NAMPT, a decrease was observed in all GSE supplemented group compared to the control group $(P<0.0005)$. In theca cells, we observed a decrease in GPR1 expression in $D$ group as compared to the control $(P=0.05)$. There was not statistical difference for the other genes. 
Table 5

mRNA expression of adipokines (RARRES2, ADIPOQ, NAMPT) and their receptors (CMKLR1, CCRL2, GPR1, ADIPOR1, ADIPOR2) in granulosa and theca cells from preovulatory follicle 1 (F1).

\begin{tabular}{|c|c|c|c|c|c|c|c|c|c|}
\hline Tissues & Genes & A & B & C & D & TimeSuppl & $\begin{array}{l}\text { Diet } \\
\text { ABCD }\end{array}$ & $\begin{array}{l}\text { Diet } \\
A B C\end{array}$ & $\begin{array}{l}\text { Diet } \\
A D\end{array}$ \\
\hline \multirow[t]{7}{*}{$\begin{array}{l}\text { Granulosa } \\
\text { cells F1 }\end{array}$} & RARRES2 & $\begin{array}{l}0.4 \pm \\
0.09\end{array}$ & $\begin{array}{l}0.32 \pm \\
0.03\end{array}$ & $\begin{array}{l}0.33 \\
\pm 0.04\end{array}$ & $\begin{array}{l}0.3 \pm \\
0.04\end{array}$ & 0.4 & 0.61 & - & - \\
\hline & CMKLR1 & $\begin{array}{l}0.001 \\
\pm \\
2.10^{-} \\
4 a\end{array}$ & $\begin{array}{l}0.0014 \\
\pm 3.10^{-} \\
4 a\end{array}$ & $\begin{array}{l}5.10^{-} \\
4 \pm \\
5.10^{-} \\
5 \mathrm{~b}\end{array}$ & $\begin{array}{l}6.10^{-} \\
4 \pm \\
3.10^{-} \\
4 a, b\end{array}$ & 0.59 & 0.05 & - & - \\
\hline & CCRL2 & $\begin{array}{l}0.003 \\
\pm \\
7.10^{-} \\
4 a\end{array}$ & $\begin{array}{l}0.003 \\
\pm 6.10^{-} \\
4 a\end{array}$ & $\begin{array}{l}6.10^{-} \\
4 \pm \\
1.10^{-} \\
4 \mathrm{~b}\end{array}$ & $\begin{array}{l}0.001 \\
\pm \\
7.10^{-} \\
4 a\end{array}$ & 0.33 & 0.04 & - & - \\
\hline & GPR1 & $\begin{array}{l}0.5 \pm \\
0.12^{a}\end{array}$ & $\begin{array}{l}0.3 \pm \\
0.03 \text { a,b }\end{array}$ & $\begin{array}{l}0.22 \\
\pm 0.02 \\
b\end{array}$ & $\begin{array}{l}0.19 \\
\pm 0.02\end{array}$ & 0.001 & - & 0.01 & 0.03 \\
\hline & ADIPOR1 & $\begin{array}{l}0.002 \\
\pm \\
4.10^{-} \\
4\end{array}$ & $\begin{array}{l}0.002 \\
\pm 2.10^{-} \\
4\end{array}$ & $\begin{array}{l}0.003 \\
\pm \\
5.10^{-} \\
4\end{array}$ & $\begin{array}{l}0.001 \\
\pm \\
2.10^{-} \\
4\end{array}$ & 0.02 & - & 0.6 & 0.01 \\
\hline & ADIPOR2 & $\begin{array}{l}0.008 \\
\pm \\
7.10^{-} \\
4\end{array}$ & $\begin{array}{l}0.008 \\
\pm 6.10^{-} \\
4\end{array}$ & $\begin{array}{l}0.01 \\
\pm \\
0.001\end{array}$ & $\begin{array}{l}0.007 \\
\pm \\
0.001\end{array}$ & 0.16 & 0.07 & - & - \\
\hline & NAMPT & $\begin{array}{l}0.02 \\
\pm \\
0.002 \\
a\end{array}$ & $\begin{array}{l}0.01 \pm \\
0.001 \mathrm{~b}\end{array}$ & $\begin{array}{l}0.01 \\
\pm \\
0.001 \\
b\end{array}$ & $\begin{array}{l}0.009 \\
\pm \\
0.001\end{array}$ & $<0.0001$ & - & 0.0003 & 0.0002 \\
\hline \multirow[t]{4}{*}{$\begin{array}{l}\text { Theca } \\
\text { cells F1 }\end{array}$} & RARRES2 & $\begin{array}{l}0.41 \\
\pm 0.04\end{array}$ & $\begin{array}{l}0.4 \pm \\
0.04\end{array}$ & $\begin{array}{l}0.49 \\
\pm 0.03\end{array}$ & $\begin{array}{l}0.36 \\
\pm 0.03\end{array}$ & 0.22 & 0.1 & - & - \\
\hline & CMKLR1 & $\begin{array}{l}0.11 \\
\pm 0.03\end{array}$ & $\begin{array}{l}0.12 \pm \\
0.02\end{array}$ & $\begin{array}{l}0.16 \\
\pm 0.04\end{array}$ & $\begin{array}{l}0.08 \\
\pm 0.02\end{array}$ & 0.28 & 0.31 & - & - \\
\hline & CCRL2 & $\begin{array}{l}0.45 \\
\pm 0.1\end{array}$ & $\begin{array}{l}0.49 \pm \\
0.06\end{array}$ & $\begin{array}{l}0.77 \\
\pm 0.11\end{array}$ & $\begin{array}{l}0.45 \\
\pm 0.03\end{array}$ & 0.2 & 0.03 & - & - \\
\hline & GPR1 & $\begin{array}{l}0.1 \pm \\
0.02\end{array}$ & $\begin{array}{l}0.14 \pm \\
0.02\end{array}$ & $\begin{array}{l}0.08 \\
\pm 0.01\end{array}$ & $\begin{array}{l}0.05 \\
\pm \\
0.006\end{array}$ & 0.04 & - & 0.23 & 0.05 \\
\hline
\end{tabular}

Results are presented as Ismeans \pm SEM. $P$ values of the effect of the stage when the supplementation is applied (TimeSuppl) and diet were considered as significant if $P<0.05$. Different individual letters indicate a significant effect of the diet. 


\begin{tabular}{|c|c|c|c|c|c|c|c|c|c|}
\hline Tissues & Genes & A & B & C & D & TimeSuppl & $\begin{array}{l}\text { Diet } \\
\text { ABCD }\end{array}$ & $\begin{array}{l}\text { Diet } \\
A B C\end{array}$ & $\begin{array}{l}\text { Diet } \\
A D\end{array}$ \\
\hline & ADIPOQ & $\begin{array}{l}0.18 \\
\pm 0.05\end{array}$ & $\begin{array}{l}0.21 \pm \\
0.04\end{array}$ & $\begin{array}{l}0.33 \\
\pm 0.07\end{array}$ & $\begin{array}{l}0.19 \\
\pm 0.05\end{array}$ & 0.35 & 0.19 & - & - \\
\hline & ADIPOR1 & $\begin{array}{l}5.10^{-} \\
4 \pm \\
1.10^{-} \\
4\end{array}$ & $\begin{array}{l}5.10^{-4} \\
\pm \\
3.10^{-4}\end{array}$ & $\begin{array}{l}1.10^{-} \\
4 \pm \\
4.10^{-} \\
5\end{array}$ & $\begin{array}{l}4.10^{-} \\
4 \pm \\
2.10^{-} \\
4\end{array}$ & 0.84 & 0.3 & - & - \\
\hline & ADIPOR2 & $\begin{array}{l}0.002 \\
\pm \\
4.10^{-} \\
4\end{array}$ & $\begin{array}{l}0.001 \\
\pm 3.10^{-} \\
4\end{array}$ & $\begin{array}{l}0.001 \\
\pm \\
3.10^{-} \\
4\end{array}$ & $\begin{array}{l}0.001 \\
\pm \\
4.10^{-} \\
4\end{array}$ & 0.47 & 0.67 & - & - \\
\hline & NAMPT & $\begin{array}{l}0.13 \\
\pm 0.03\end{array}$ & $\begin{array}{l}0.16 \pm \\
0.02\end{array}$ & $\begin{array}{l}0.12 \\
\pm 0.02\end{array}$ & $\begin{array}{l}0.09 \\
\pm 0.01\end{array}$ & 0.17 & 0.15 & - & - \\
\hline
\end{tabular}

\section{Discussion}

This present study shows for the first time that an in vivo GSE maternal dietary supplementation very early (at hatch) or lately (at week 4) reduces significantly ROS levels and steroid secretion in yolk egg and this was associated to variations of plasma and ovarian cell adipokines in reproductive broiler hens. Furthermore we showed that this GSE supplementation ameliorated egg quality by decreasing the number of double-yolk eggs and by improving the elasticity of the shell. All these data were observed without any alterations in fertility parameters and egg production.

\section{GSE reduced ROS level in egg yolk}

Our results indicate that a dietary GSE supplementation significantly reduces the ROS levels in egg yolk suggesting a reduction in both lipid peroxidation and OS. These data can be considered beneficial since yolk oxidation leads to malondialdehyde production (product of lipid peroxidation, that is a toxic substance with negative effects on human and animal health (33). A significant reduction on lipid peroxidation and increased antioxidant capacity in egg yolk were found in laying hens fed with grape pomace flour, as observed by Kara et al. (34) (35) and Galli et al. (36) in laying hens fed grape pomace and curcumin, respectively. GSE are known to decrease oxidative stress and ROS in various tissues or cells under different conditions. For example, in rats, GSE treatment decreased oxidative stress damage in liver following bile duct ligation (37) or high fat diet (38). In broiler chicken, grape seed proanthocyanidin extracts decreases oxidative damages induced by aflatoxins in splenic tissues (39). Thus, maternal dietary GSE supplementation is able to scavenge free oxygen radical in the egg yolk as it has been demonstrated in mammalian and chicken tissue. 
Dietary GSE supplementation did not affect the egg production but improved the quality of eggs by decreasing the number of double-yolk eggs and by increasing the shell elasticity

We did not observe any effect of the supplementation on the egg production rate or the egg weight during the whole laying period (23-40 weeks). However, the GSE supplementation reduced the incidence of double-yolk eggs. The double-yolked avian egg is a common physiological process in commercial species of poultry (40, 41). Double-yolk eggs are formed when two F1 follicles ovulated within three hours of each other become enclosed in one egg (42), and estimated to occur in 4 12.5\% of broiler breeder pullet eggs in the first 3 months of laying $(43,44)$. Double-yolk eggs are considered as a loss to overall commercial hatcheries because of their relatively lower yolk fertility rate due to their smaller yolk size and markedly lower hatchability rate (40, 45). Thus, maternal dietary GSE supplementation could have a beneficial for the breeders. Interestingly, we found that eggs from hens fed with the diet supplemented with 1\% GSE from 4 week-old were heaver, bigger and larger compared to the control at 33 weeks and we noticed a higher elasticity of the shell for all supplemented group. Until now no studies investigated the GSE extract on the egg performance and quality. However, Sahin K et al., 2010 reported no effects of dietary resveratrol supplementation on egg production or egg quality related to the shell, yolk and albumen in quails (46). Resveratrol is an antioxidant located in whole grape and has properties similar to proanthocyanidin, the main component in grape seed (47).

\section{GSE supplementation did not affect the fertility parameters}

Since the GSE supplementation reduced ROS levels in yolk and high levels of ROS are known to alter fertility, we expected a better fertility in supplemented animals. However, we observed no significant effect on the embryo viability, hatchability or fertility rate. These data could be explained by several reasons; first the percentage of fertility of animals could be too high (almost 90\%) to observe a beneficial effect, second the levels of ROS in yolk if important in fertility regulation in control group were not high enough to induce a deleterious effect on the fertilization process or embryo development, finally the time of GSE supplementation was too long. At the opposite in the literature, a dietary selenium (antioxidant) supplementation increased hatchability and reduced embryonic mortality rate $(48,49)$. Furthermore, using in ovo injection (at embryonic day 6.5), GSE has been shown to protect chicken embryos against Cadmium, an endocrine disruptor (29).

\section{GSE supplementation decreased steroidogenesis in egg yolk and basal progesterone production by cultured granulosa cells}

Although the GSE supplementation did not affect fertility parameters, we observed a reduction in steroid content in yolk egg and this was associated to a lower production of progesterone and a lower expression of StAR and P450 aromatase by granulosa cells. Some studies showed that the steroid hormones of maternal origin in avian egg yolks have a strong influence on offspring development $(50,51)$. Thus, it will be interesting to follow the growth of chicks from hens fed with a diet supplemented with GSE. In vitro, we observed that F1 granulosa cells from hens fed with a diet supplemented with GSE were more sensitive to IGF1 and LH alone or in combination concerning progesterone production. Several studies showed that GSE treatment improves insulin sensitivity by increasing expression and activation of insulin receptor signalling components (52). Since insulin receptors and IGF1 receptors share a high similarity of structure and intracellular signalling components (53), we can hypothesize that GSE treatment improves IGF1 receptor signaling in hen granulosa cells. No effect of GSE treatment on LH receptor has yet described in the literature. In basal state (no IGF1 and 
LH stimulation), progesterone secretion is lower in granulosa cells from hens fed with a diet supplemented with GSE. In a recent paper, we showed a positive effect of GSE treatment on progesterone and oestradiol secretion by cultured human granulosa cells (54). This discrepancy of the results between the two studies could be explained by the fact that the hen granulosa cells were indirectly exposed to GSE treatment (through maternal diet). It will be interesting to determine the composition in polyphenols of the preovulatory follicles to determine which polyphenols are exposed to granulosa cells.

GSE supplementation modulated plasma adipokines concentration: a link with steroidogenesis and ROS level in egg yolk

In plasma, we found that GSE treatment decreases RARRES2 and increases ADIPOQ and NAMPT. Furthermore, we observed that plasma RARRES2 was positively associated to ROS levels and steroid production in yolk egg. Opposite results were observed for plasma ADIPOQ and NAMPT. RARRES2 has been already described involved in the regulation of the OS. Indeed, RARRES2 increased ROS levels in C2C12 myoblasts (55) and upregulation of RARRES2 and one of these receptors, CMKLR1 may explain the imbalance of OS and apoptosis in the ovaries of obese mice (56). In hen granulosa cells, maternal dietary GSE supplementation at week 4 significantly reduced CMKLR1 and GPR1 mRNA expression suggesting that RARRES2 signaling could participate to the reduction of ROS levels in yolk egg. The increase in plasma ADIPOQ in response to maternal diet GSE supplementation in hens is a good agreement with data obtained in mammals. Indeed, in rats, maternal intake of GSE induces an increase of ADIPOQ in plasma (57). Moreover, ADIPOQ treatment significantly decreases the production of intercellular ROS (58). NAMPT is involved in oxidative stress processes and is responsible for the production of NAD, which is involved in cellular redox reactions. The inhibition of NAMPT decreased cell growth and enhanced susceptibility to oxidative stress. NAMPT enhances ROS production in human vascular endothelial cells (59) and induces oxidative stress in differentiated C2C12 myotubes (60). Furthermore, NAMPT expression can be modulated by GSE treatment in rat liver (61). All these data suggest that plasma and ovarian expression of adipokines could participate to regulate the ROS levels and OS in yolk egg and ovarian cells in hens fed with a diet supplemented with GSE.

\section{Conclusions}

In conclusion, we showed that a maternal diet GSE supplementation at hatch or at 4 week-old until 40 week-old significantly improved the quality of eggs by decreasing the number of double-yolk eggs and by increasing the shell elasticity without affecting the egg production and fertility parameters. Furthermore, GSE supplementation reduced the levels of ROS and steroidogenesis in yolk egg and this was associated to variations in plasma and ovarian cell expression of adipokines. Taken together, our data suggest the possibility of using dietary maternal GSE to improve egg quality. However, more experiments are necessary to investigate the effect of sequential maternal dietary GSE supplementation for a short time at specific period such as prelaying on the fertility parameters and laying performance in adult offspring.

\section{Abbreviations}

ACTB

Actin- $\beta$

Page $18 / 30$ 
ADIPOQ

Adiponectin

ADIPOR1

Adiponectin receptor 1

ADIPOR2

Adiponectin receptor 2

Al

Artificial insemination

CCK8

Cell counting kit-8

CCRL2

C-C chemokine receptor like 2

CMKLR1

Chemokine-like receptor 1

EEM

Early embryonic mortality

EIF3

Eukaryotic initiation factor 3

GAPDH

Glyceraldehyde 3-phosphate dehydrogenase

GPR1

$\mathrm{G}$ protein-coupled receptor 1

GSE

Grape seed extract

IGF-1

Insulin growth factor-1

LEM

Late embryonic mortality

$\mathrm{LH}$

Luteinizing hormone

$\mathrm{NADPH}$

Nicotinamide adenine dinucleotide phosphate

NAMPT

Nicotinamide phosphoribosyltransferase

NO

Nitric oxide

OS

Oxidative stress

RARRES2

Retinioc acid receptor responder 2

ROS

Reactive oxygen species 


\section{Declarations}

\section{Ethics approval and consent to participate}

An ethics committee "Comité d'Ethique en Expérimentation Animale Val de Loire " (CEEA VdL N¹9) protocol registered approved all experimental studies, which were in accordance with the French National Guidelines for the care and use of animals for research purposes (certificate of authorisation to experiment on living animals APAFIS number 10237-201706151202940v3).

\section{Consent for publication}

Not applicable.

\section{Availability of data and materials}

The dataset supporting the conclusions of this article is included within the article (and its Additional files 1 to $3)$.

\section{Competing interests}

The authors declare that they have no competing interests.

\section{Funding}

The authors are grateful to the Région Centre Val de Loire for the supporting grant 'PREVADI' $N^{\circ} 32000820$ and for the supporting grant for Alix Barbe as a PhD student.

\section{Authors' contributions}

JD participated in its design and coordination and drafted the manuscript and advised on the statistical analysis. $A B, N M, C R, J G, M C, P G, A B, A R$ and $P F$ participated in the design of the study and carried out management of the animals, the collection of plasma and tissue samples, and participated in drafting the manuscript. All authors read and approved the final manuscript.

\section{Acknowledgements}

We thank François Mairel for all discussions about GSE. We thank all the INDENA members who participated to the preparation of the GSE.

\section{Authors' information (optional)}




\section{References}

1. Betteridge DJ. What is oxidative stress? Metabolism. 2000;49(2 Suppl 1):3-8.

2. Burton GJ, Jauniaux E. Oxidative stress. Best Pract Res Clin Obstet Gynaecol. 2011;25(3):287-99.

3. Schieber M, Chandel NS. ROS function in redox signaling and oxidative stress. Curr Biol. 2014;24(10):R453-62.

4. Agarwal A, Gupta S, Sharma R. Oxidative stress and its implications in female infertility - a clinician's perspective. Reprod Biomed Online. 2005;11(5):641-50.

5. Pandey AN, Tripathi A, Premkumar KV, Shrivastav TG, Chaube SK. Reactive oxygen and nitrogen species during meiotic resumption from diplotene arrest in mammalian oocytes. J Cell Biochem. 2010;111(3):5218.

6. Shkolnik K, Tadmor A, Ben-Dor S, Nevo N, Galiani D, Dekel N. Reactive oxygen species are indispensable in ovulation. Proc Natl Acad Sci U S A. 2011;108(4):1462-7.

7. Tripathi A, Khatun S, Pandey AN, Mishra SK, Chaube R, Shrivastav TG, et al. Intracellular levels of hydrogen peroxide and nitric oxide in oocytes at various stages of meiotic cell cycle and apoptosis. Free Radic Res. 2009;43(3):287-94.

8. Prasad S, Tiwari M, Pandey AN, Shrivastav TG, Chaube SK. Impact of stress on oocyte quality and reproductive outcome. J Biomed Sci. 2016;23:36.

9. Rizzo A, Roscino MT, Binetti F, Sciorsci RL. Roles of reactive oxygen species in female reproduction. Reprod Domest Anim. 2012;47(2):344-52.

10. Tripathi A, Shrivastav TG, Chaube SK. An increase of granulosa cell apoptosis mediates aqueous neem (Azadirachta indica) leaf extract-induced oocyte apoptosis in rat. Int J Appl Basic Med Res. 2013;3(1):2736.

11. Gupta S, Agarwal A, Krajcir N, Alvarez JG. Role of oxidative stress in endometriosis. Reprod Biomed Online. 2006;13(1):126-34.

12. Sobinoff AP, Sutherland JM, McLaughlin EA. Intracellular signalling during female gametogenesis. Mol Hum Reprod. 2013;19(5):265-78.

13. Stanley JA, Sivakumar KK, Arosh JA, Burghardt RC, Banu SK. Edaravone mitigates hexavalent chromiuminduced oxidative stress and depletion of antioxidant enzymes while estrogen restores antioxidant enzymes in the rat ovary in F1 offspring. Biol Reprod. 2014;91(1):12.

14. Opuwari CS, Henkel RR. An Update on Oxidative Damage to Spermatozoa and Oocytes. Biomed Res Int. 2016;2016:9540142.

15. Snider AP, Wood JR. Obesity induces ovarian inflammation and reduces oocyte quality. Reproduction. 2019;158(3):R79-R90.

16. Chen SE, McMurtry JP, Walzem RL. Overfeeding-induced ovarian dysfunction in broiler breeder hens is associated with lipotoxicity. Poult Sci. 2006;85(1):70-81.

17. Decuypere E, Bruggeman V, Everaert N, Li Y, Boonen R, De Tavernier J, et al. The broiler breeder paradox: ethical, genetic and physiological perspectives, and suggestions for solutions. Br Poult Sci. 
2010;51(5):569-79.

18. Richards MP, Proszkowiec-Weglarz M. Mechanisms regulating feed intake, energy expenditure, and body weight in poultry. Poult Sci. 2007;86(7):1478-90.

19. Leeson S, Summers JD, Caston LJ. Response of layers to dietary flaxseed according to body weight classification at maturity. Journal of Applied Poultry Research. 2000;9(3):297-302.

20. Estevez M. Oxidative damage to poultry: from farm to fork. Poult Sci. 2015;94(6):1368-78.

21. Bagchi D, Bagchi M, Stohs SJ, Das DK, Ray SD, Kuszynski CA, et al. Free radicals and grape seed proanthocyanidin extract: importance in human health and disease prevention. Toxicology. 2000;148(23):187-97.

22. Bagchi D, Swaroop A, Preuss HG, Bagchi M. Free radical scavenging, antioxidant and cancer chemoprevention by grape seed proanthocyanidin: an overview. Mutat Res. 2014;768:69-73.

23. Olaku OO, Ojukwu MO, Zia FZ, White JD. The Role of Grape Seed Extract in the Treatment of Chemo/Radiotherapy Induced Toxicity: A Systematic Review of Preclinical Studies. Nutr Cancer. 2015;67(5):730-40.

24. Downing LE, Ferguson BS, Rodriguez K, Ricketts ML. A grape seed procyanidin extract inhibits HDAC activity leading to increased Pparalpha phosphorylation and target-gene expression. Mol Nutr Food Res. 2017;61(2).

25. Gonzalez-Abuin N, Martinez-Micaelo N, Margalef M, Blay M, Arola-Arnal A, Muguerza B, et al. A grape seed extract increases active glucagon-like peptide-1 levels after an oral glucose load in rats. Food Funct. 2014;5(9):2357-64.

26. Decorde K, Agne A, Lacan D, Ramos J, Fouret G, Ventura E, et al. Preventive effect of a melon extract rich in superoxide scavenging activity on abdominal and liver fat and adipokine imbalance in high-fat-fed hamsters. J Agric Food Chem. 2009;57(14):6461-7.

27. Barbe A, Bongrani A, Mellouk N, Estienne A, Kurowska P, Grandhaye J, et al. Mechanisms of Adiponectin Action in Fertility: An Overview from Gametogenesis to Gestation in Humans and Animal Models in Normal and Pathological Conditions. Int J Mol Sci. 2019;20(7).

28. Liu XT, Lin X, Mi YL, Li J, Zhang CQ. Grape Seed Proanthocyanidin Extract Prevents Ovarian Aging by Inhibiting Oxidative Stress in the Hens. Oxidative Medicine and Cellular Longevity. 2018.

29. Hou FY, Xiao M, Li J, Cook DW, Zeng WD, Zhang CQ, et al. Ameliorative Effect of Grape Seed Proanthocyanidin Extract on Cadmium-Induced Meiosis Inhibition During Oogenesis in Chicken Embryos. Anatomical Record-Advances in Integrative Anatomy and Evolutionary Biology. 2016;299(4):450-60.

30. Etches RJ, Petitte JN. Reptilian and Avian Follicular Hierarchies - Models for the Study of Ovarian Development. Journal of Experimental Zoology. 1990:112-22.

31. Canepa S BLA, Fagu C, Flon C, Monniaux D. Validation d'une methode immunoenzymatique pour le dosage de la progesterone dans le plasma des ovins et des bovins. Les Cahiers Techniques de L'INRA. 2008;64:19-30.

32. Mellouk N, Rame C, Delaveau J, Rat C, Marchand M, Mercerand F, et al. Food restriction but not fish oil increases fertility in hens: role of RARRES2? Reproduction. 2018;155(4):321-31. 
33. Pearson AM, Gray JI, Wolzak AM, Horenstein NA. Safety Implications of Oxidized Lipids in Muscle Foods. Food Technol-Chicago. 1983;37(7):121-9.

34. Kara K, Guclu BK, Baytok E, Senturk M. Effects of grape pomace supplementation to laying hen diet on performance, egg quality, egg lipid peroxidation and some biochemical parameters. J Appl Anim Res. 2016;44(1):303-10.

35. Reis JH, Gebert RR, Barreta M, Boiago MM, Souza CF, Baldissera MD, et al. Addition of grape pomace flour in the diet on laying hens in heat stress: Impacts on health and performance as well as the fatty acid profile and total antioxidant capacity in the egg. J Therm Biol. 2019;80:141-9.

36. Galli GM, Da Silva AS, Biazus AH, Reis JH, Boiago MM, Topazio JP, et al. Feed addition of curcumin to laying hens showed anticoccidial effect, and improved egg quality and animal health. Res Vet Sci. 2018;118:101-6.

37. Dulundu E, Ozel Y, Topaloglu U, Toklu H, Ercan F, Gedik N, et al. Grape seed extract reduces oxidative stress and fibrosis in experimental biliary obstruction. J Gastroenterol Hepatol. 2007;22(6):885-92.

38. Choi SK, Zhang XH, Seo JS. Suppression of oxidative stress by grape seed supplementation in rats. Nutr Res Pract. 2012;6(1):3-8.

39. Rajput SA, Sun L, Zhang NY, Khalil MM, Ling Z, Chong L, et al. Grape Seed Proanthocyanidin Extract Alleviates AflatoxinB(1)-Induced Immunotoxicity and Oxidative Stress via Modulation of NF-kappaB and Nrf2 Signaling Pathways in Broilers. Toxins (Basel). 2019;11(1).

40. Bailey RL, Clark GE. Occurrence of twin embryos in the eastern bluebird. PeerJ. 2014;2:e273.

41. Deeming DC. Double-yolked pheasant eggs provide an insight into the control of albumen secretion in bird eggs. Br Poult Sci. 2011;52(1):40-7.

42. Warren DC SH. The time factor in egg formation. . Poultry Science. 1935; 14(4):195-207.

43. Fasenko GM, Robinson FE, Danforth BL, Zelter I. An examination of fertility, hatchability, embryo mortality, and chick weight in double versus single-yolked broiler breeder eggs. Can J Anim Sci. 2000;80(3):489-93.

44. Jaap RG, Muir FV. Erratic Oviposition and Egg Defects in Broiler-Type Pullets. Poultry Sci. 1968;47(2):417$\&$.

45. Fechheimer NS, Jaffe WP. Fertility and embryo death in double-yolked eggs. J Reprod Fertil. 1966;12(2):363-4.

46. Sahin K, Akdemir F, Orhan C, Tuzcu M, Hayirli A, Sahin N. Effects of dietary resveratrol supplementation on egg production and antioxidant status. Poult Sci. 2010;89(6):1190-8.

47. Xia EQ, Deng GF, Guo YJ, Li HB. Biological activities of polyphenols from grapes. Int J Mol Sci. 2010;11(2):622-46.

48. Emamverdi M, Zare-Shahneh A, Zhandi M, Zaghari M, Minai-Tehrani D, Khodaei-Motlagh M. An improvement in productive and reproductive performance of aged broiler breeder hens by dietary supplementation of organic selenium. Theriogenology. 2019;126:279-85.

49. Latshaw JD, Ort JF, Diesem CD. The selenium requirements of the hen and effects of a deficiency. Poult Sci. 1977;56(6):1876-81.

50. Gil D, Bulmer E, Celis P, Puerta M. Increased sibling competition does not increase testosterone or corticosterone levels in nestlings of the spotless starling (Sturnus unicolor). Horm Behav. 2008;54(2):238- 
43.

51. Groothuis TG, Muller W, von Engelhardt N, Carere C, Eising C. Maternal hormones as a tool to adjust offspring phenotype in avian species. Neurosci Biobehav Rev. 2005;29(2):329-52.

52. Meeprom A, Sompong W, Suwannaphet W, Yibchok-anun S, Adisakwattana S. Grape seed extract supplementation prevents high-fructose diet-induced insulin resistance in rats by improving insulin and adiponectin signalling pathways. Br J Nutr. 2011;106(8):1173-81.

53. Dupont J, LeRoith D. Insulin and insulin-like growth factor I receptors: similarities and differences in signal transduction. Horm Res. 2001;55 Suppl 2:22-6.

54. Barbe A, Rame C, Mellouk N, Estienne A, Bongrani A, Brossaud A, et al. Effects of Grape Seed Extract and Proanthocyanidin B2 on In Vitro Proliferation, Viability, Steroidogenesis, Oxidative Stress, and Cell Signaling in Human Granulosa Cells. Int J Mol Sci. 2019;20(17).

55. Li HX, Chen KL, Wang HY, Tang CB, Xu XL, Zhou GH. Chemerin inhibition of myogenesis and induction of adipogenesis in C2C12 myoblasts. Mol Cell Endocrinol. 2015;414:216-23.

56. Yao J, Li Z, Fu Y, Wu R, Wang Y, Liu C, et al. Involvement of obesity-associated upregulation of chemerin/chemokine-like receptor 1 in oxidative stress and apoptosis in ovaries and granulosa cells. Biochem Biophys Res Commun. 2019;510(3):449-55.

57. Caimari A, Marine-Casado R, Boque N, Crescenti A, Arola L, Del Bas JM. Maternal intake of grape seed procyanidins during lactation induces insulin resistance and an adiponectin resistance-like phenotype in rat offspring. Sci Rep. 2017;7(1):12573.

58. Wang F, Liu Y, Yang W, Yuan J, Mo Z. Adiponectin inhibits NLRP3 inflammasome by modulating the AMPK-ROS pathway. Int J Clin Exp Pathol. 2018;11(7):3338-47.

59. Lin YT, Chen LK, Jian DY, Hsu TC, Huang WC, Kuan TT, et al. Visfatin Promotes Monocyte Adhesion by Upregulating ICAM-1 and VCAM-1 Expression in Endothelial Cells via Activation of p38-PI3K-Akt Signaling and Subsequent ROS Production and IKK/NF-kappaB Activation. Cell Physiol Biochem. 2019;52(6):1398411.

60. Oita RC, Ferdinando D, Wilson S, Bunce C, Mazzatti DJ. Visfatin induces oxidative stress in differentiated C2C12 myotubes in an Akt- and MAPK-independent, NFkB-dependent manner. Pflugers Arch. 2010;459(4):619-30.

61. Ribas-Latre A, Baselga-Escudero L, Casanova E, Arola-Arnal A, Salvado MJ, Blade C, et al. Dietary proanthocyanidins modulate BMAL1 acetylation, Nampt expression and NAD levels in rat liver. Sci Rep. 2015;5:10954.

\section{Figures}



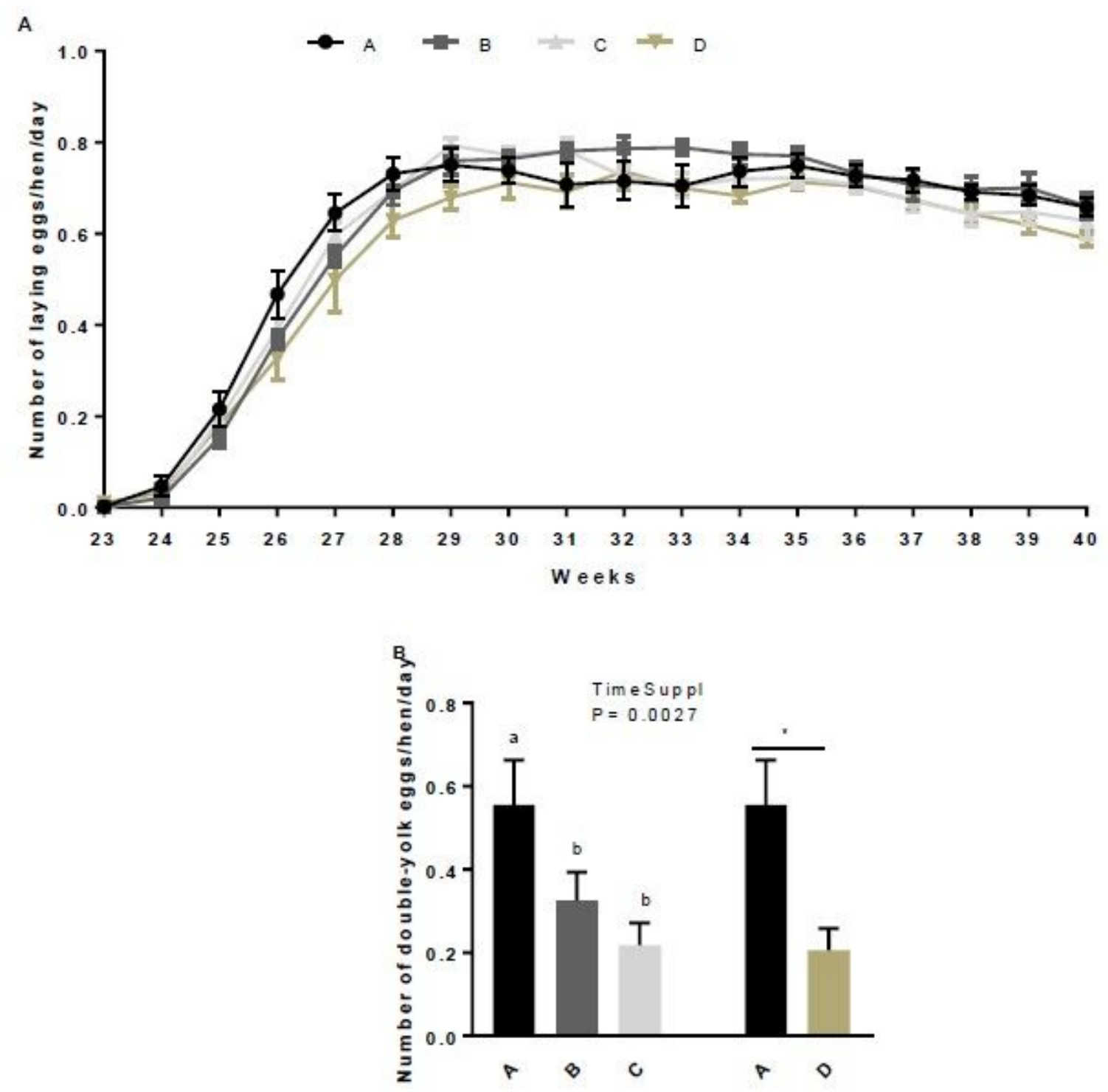

Figure 1

Laying curve (A) and number of double-yolk eggs (B) in broiler hens from 23rd to 40th week. Eggs were collected and weighed daily for all hens fed with different concentrations of GSE dietary supplementation or with a control diet. A: animals fed with control diet without GSE supplementation $(n=92), B$ and C: animals supplemented with GSE at $0.5 \%$ and $1 \%$ of the total diet composition, respectively, starting at 4 week-old until 40 week-old $(n=80)$, and D: supplementation with GSE at $1 \%$ of the total diet composition starting at hatch until 40 week-old $(n=72)$. Results are presented as Ismeans \pm S.E.M. 
A

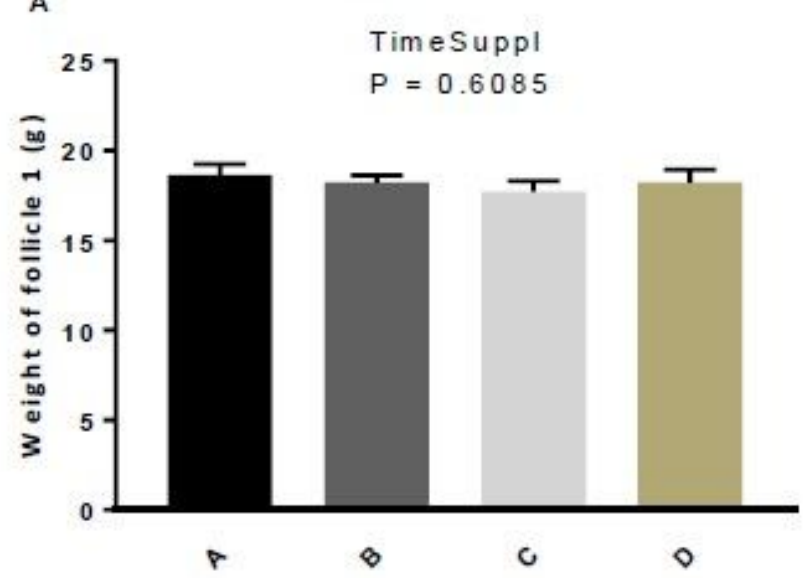

c

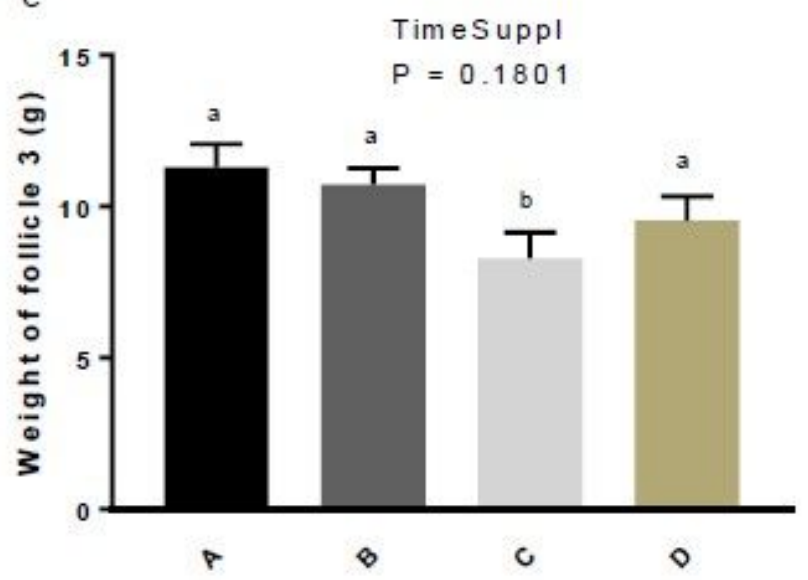

B

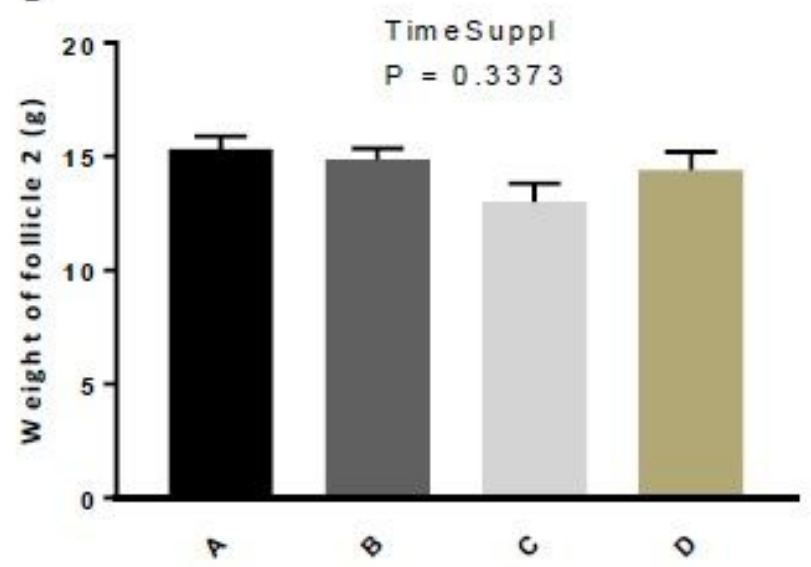

D Timesuppl

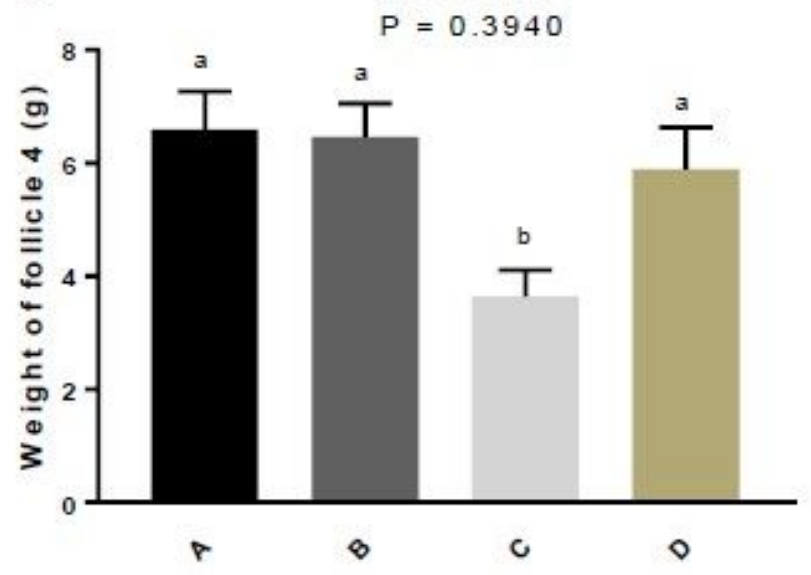

\section{Figure 2}

Weight of preovulatory follicles F1 (A), F2 (B), F3 (C) and F4 (D) of broiler hens fed with different concentrations of GSE supplementation. Follicular hierarchy of 10 animals selected randomly from each group (A to D) was analysed at the 40th week. Each preovulatory follicle from each animal was weighed. A: animals fed with control diet without GSE supplementation, B and C: animals supplemented with GSE at $0.5 \%$ and $1 \%$ of the total diet composition, respectively, starting at 4 week-old until 40 week-old, and D: supplementation with GSE at $1 \%$ of the total diet composition starting at hatch until 40 week-old. Results are presented as Ismeans \pm S.E.M. P values of the effect of the stage when the supplementation is applied (TimeSuppl) and diet were considered as significant if $P<0.05$. Different individual letters indicate a significant effect of the diet. 
A
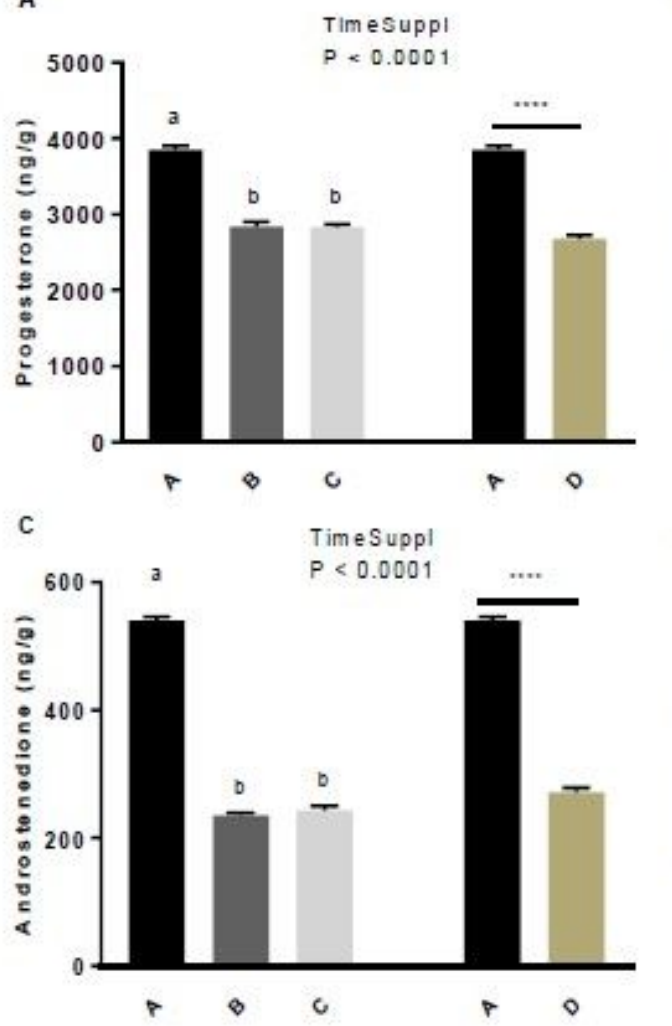

E

P450 Arom atase

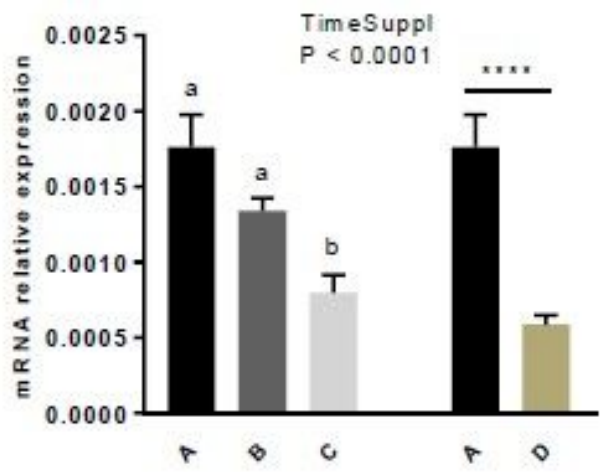

B
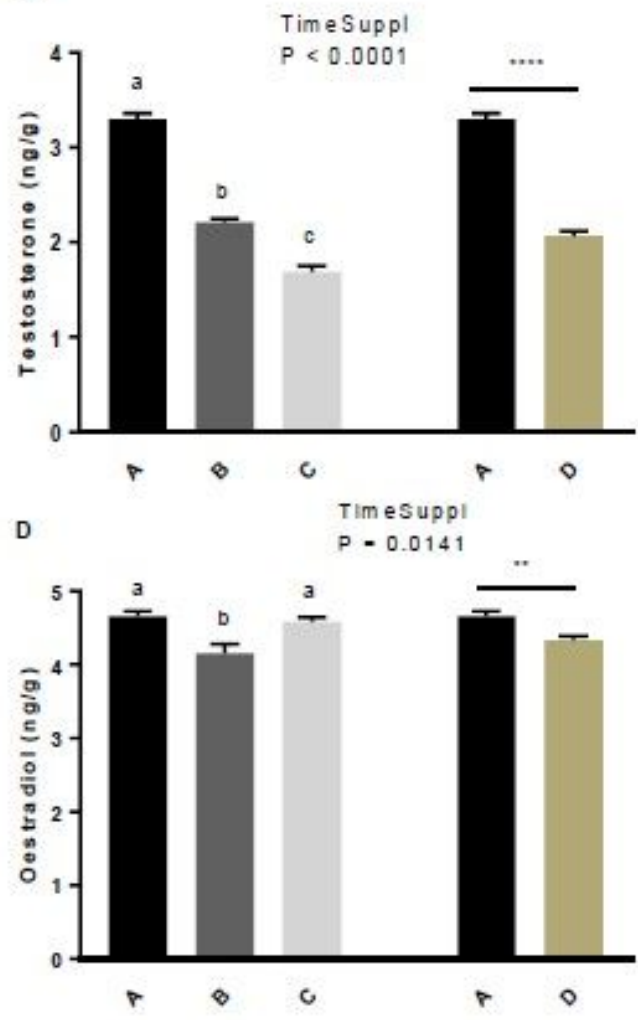

$\mathrm{F}$

StAR

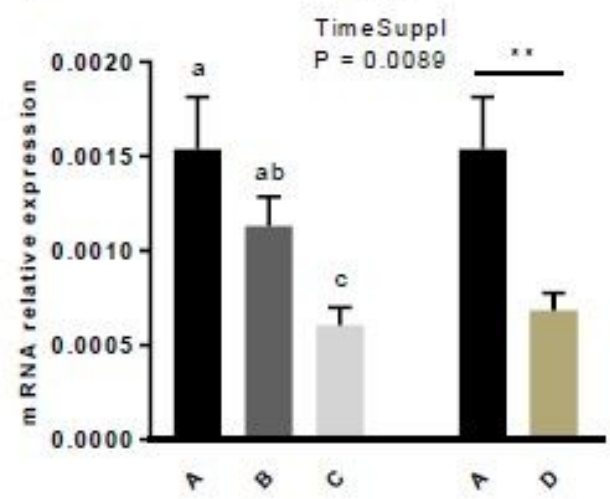

Figure 3

Levels of progesterone (A), testosterone (B), androstenedione (C) and oestradiol (D) in egg yolk and P450 aromatase (E) and StAR (F) mRNA expression in granulosa cell from broiler hens fed with different concentrations of GSE. Steroids were extracted from 30 egg yolks for each group, at 33 weeks-old. mRNA was extracted from granulosa cells of 10 preovulatory follicles for each group. A: animals fed with control diet without GSE supplementation, B and C: animals supplemented with GSE at $0.5 \%$ and $1 \%$ of the total diet composition, respectively, starting at 4 week-old until 40 week-old, and D: supplementation with GSE at $1 \%$ of the total diet composition starting at hatch until 40 week-old. Results are presented as Ismeans \pm S.E.M. P values of the effect of the stage when the supplementation is applied (TimeSuppl). Different individual letters

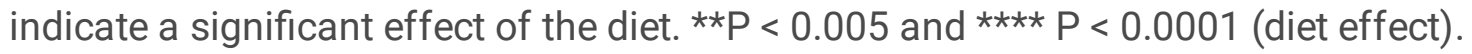




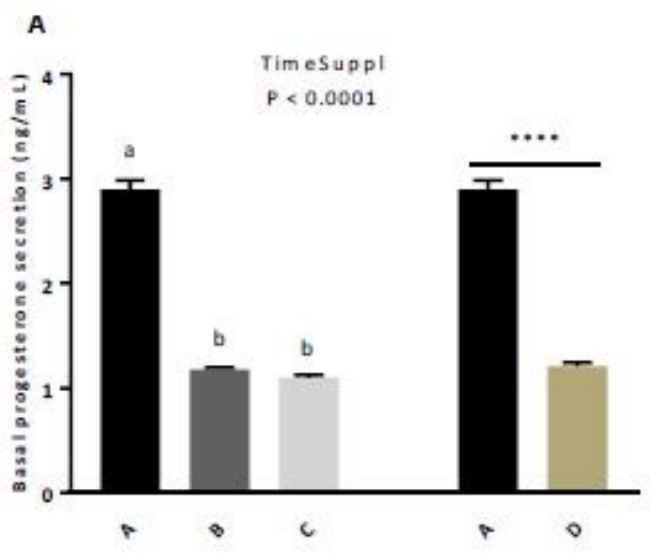

B

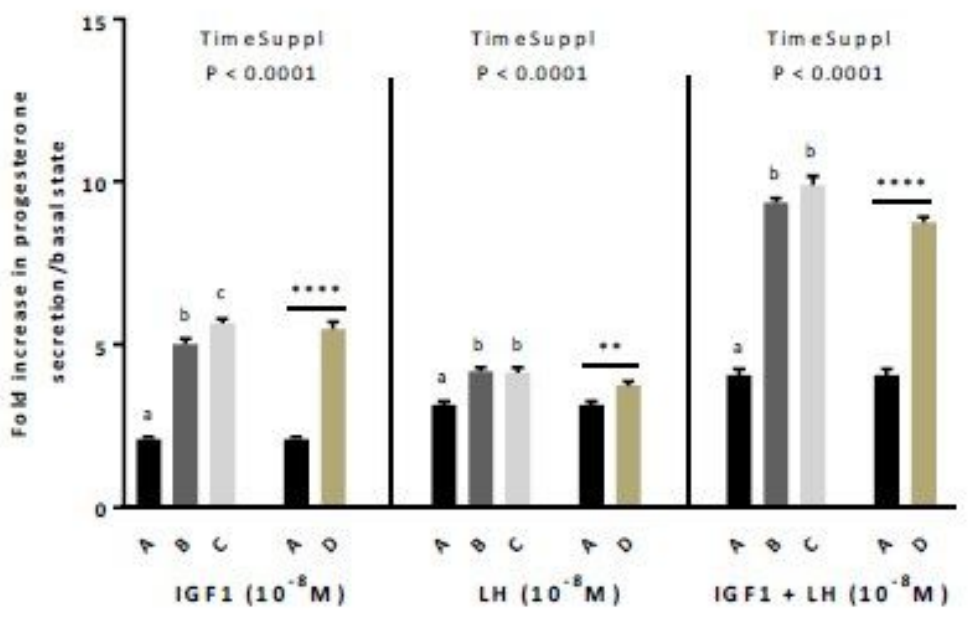

\section{Figure 4}

Effect of dietary GSE supplementation on in vitro steroidogenesis at basal state (A) and in response to IGF1 and LH alone or in combination in hen primary granulosa cells. Granulosa cells from preovulatory follicles 1 (F1) from different group of animals ( $A$ to $D$ ) were seeded for $24 \mathrm{~h}$ and after overnight serum starvation, granulosa cells were incubated with IGF1 (10-8M), LH (10-8M) or both for $48 \mathrm{~h}$. The culture medium was then collected. Basal progesterone level (A) and the response to IGF1 or/and LH (B) were assessed. A: animals fed with control diet without GSE supplementation, B and C: animals supplemented with GSE at $0.5 \%$ and $1 \%$ of the total diet composition, respectively, starting at 4 week-old until 40 week-old, and D: supplementation with GSE at $1 \%$ of the total diet composition starting at hatch until 40 week-old. Results are presented as Ismeans \pm S.E.M. $P$ values of the effect of the stage when the supplementation is applied (TimeSuppl). Different

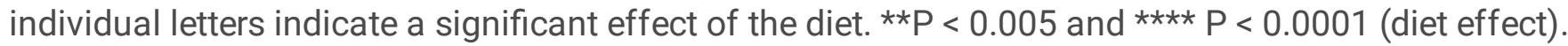




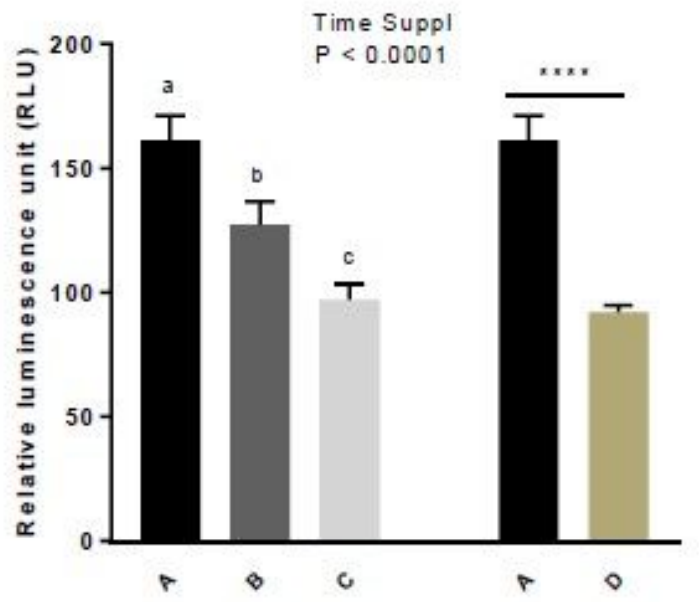

\section{Figure 5}

Level of Reactive Oxygen Species (ROS, H202) in egg yolk of broiler hens fed with different concentrations of GSE dietary supplementation. ROS level (H202) was assessed from $1 \mathrm{~g}$ of each egg yolk using Ros-Glo assay. Ten egg yolk were analysed for each group of animals. A: animals fed with control diet without GSE supplementation, B and C: animals supplemented with GSE at $0.5 \%$ and $1 \%$ of the total diet composition, respectively, starting at 4 week-old until 40 week-old, and D: supplementation at $1 \%$ of the total diet composition starting at the hatching until 40 week-old. Results are presented as Ismeans \pm S.E.M. P values of the effect of the stage when the supplementation is applied (TimeSuppl). Different individual letters indicate a significant effect of the diet. ${ }^{\star \star \star \star} \mathrm{P}<0.0001$ (diet effect). 

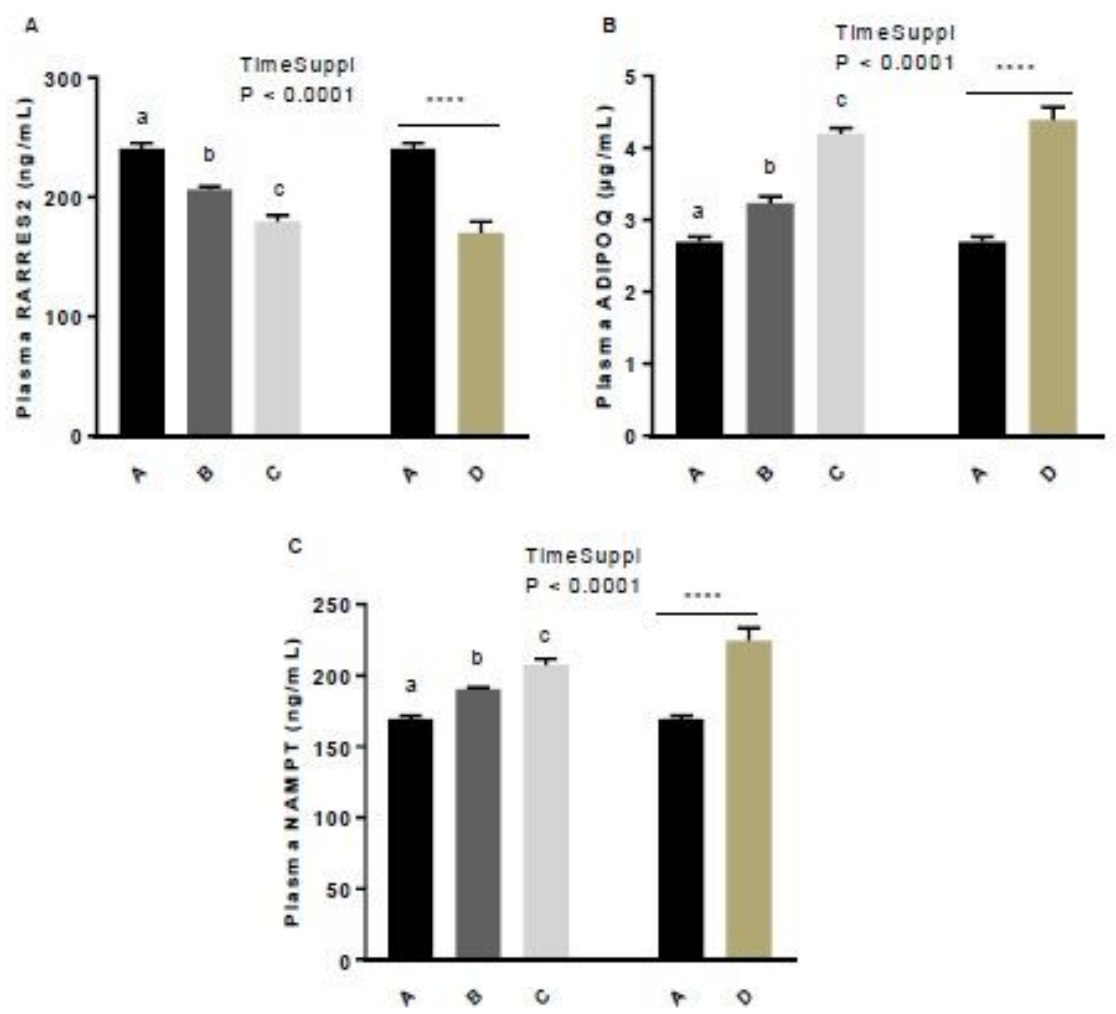

\section{Figure 6}

Level of plasma RARRES2 (A), ADIPOQ (B) and NAMPT( C) concentrations of broiler hens fed with different concentrations of GSE dietary supplementation. At 33rd week, plasma adipokines concentration was assessed using specific ELISA assay in 11 animals from each group of animals. A: animals fed with control diet without GSE supplementation, B and C: animals supplemented with GSE at $0.5 \%$ and $1 \%$ of the total diet composition, respectively, starting at 4 week-old until 40 week-old, and D: supplementation at $1 \%$ of the total diet composition starting at hatch until 40 week-old. Results are presented as Ismeans \pm S.E.M. P values of the effect of the stage when the supplementation is applied (TimeSuppl). Different individual letters indicate a significant effect of the diet. ${ }^{\star \star \star \star} \mathrm{P}<0.0001$ (diet effect).

\section{Supplementary Files}

This is a list of supplementary files associated with this preprint. Click to download.

- allsupplementalfigures.pdf 